УДК 78.071.1(477)(092):782]:78.01«18»

DOI https://doi.org/10.31723/2524-0447-2021-32-2-5

\author{
Олена Миколаӥвна Яструб \\ ORCID: 0000-0001-7503-7543
}

здобувач поза аспірантурою на здобуття ступеня «доктор філософії» першого року навчання (кафедра інтерпретології та аналізу музики),

викладач кафедри хорового диригування

Харківського національного університету мистецтв

імені І. П. Котларевського

olenayastrub@gmail.com

\title{
ОПЕРА «РІЗДВЯНА НІЧ» М. ЛИСЕНКА: УКРАЇНСЬКА КАРТИНА СВІТУ ХІХ СТОЛІТТЯ
}

Мета роботи полягає в актуалізації опери М. Лисенка «Різдвяна ніч» (1872 рік) у сучасному дослідницькому дискурсі - як увиразнення національної української картини світу. Методологія дослідження спирається на залучення історіографічного, жанрового, структурно-функціонального методів. Наукова новизна полягає в залученні категоріі «картина світу» як когнітивного інструменту під час вивчення музичних артефактів національної музичної культури, в даному разі - першої видатної української опери без розмовних діалогів на український текст «Різдвяна ніч» М. Лисенка, що відкриває перспективу подальшого розроблення дослідження оперної спадщини композитора як цілісності, зважаючи на системоутворювальну функцію картини світу як наукової моделі пізнання. Висновки. На підставі здійсненого дослідження узагальнимо прояв визначальних критеріїв української картини світу, виявлених в опері «Різдвяна ніч» М. Лисенка: спадкоємність (апелювання до усталених засад народнопісенної традиції та обрядових дійств - традиційної звичаєвості загалом); духовність (утілена через звернення до відповідних жанрів народнопісенної традиції, пов'язаних з оспівуванням Різдва Христового, які звучать в опері в хорових епізодах $i$ сценах); музичний логос (наслідування принципів народного багатоголосся на рівні музичної мови, що втілюється в хорових епізодах та сценах опери). Ознайомившись з наявними в наш час аудіозаписами опери «Різдвяна ніч» (1952, 1958 та 1992 років), доходимо висновку про вирішальне значення хорових сцен в опері та цінності кожної із задіяних М. Лисенком колядок, вилучення яких з опери унеможливлюе втілення художнього задуму в повноті. Завдяки унікальній художній концепиіі оперного шедевра М. Лисенка слухач сьогодення здатен осягнути велич національної традиції в їі спадкоємних зв'язках. «Різдвяна ніч» постає втіленням української картини світу ХІХ століття, дослідження якої, як і інших знакових явищ національної музичної культури, у наш час

(C) Яструб О. М., 2021 
з історичної дистанції відкриває перспективу ї̈ оцінки $i$ значення під кутом зору національної самосвідомості культури.

Ключові слова: оперна творчість М. Лисенка, хор, українська картина світу, колядка, духовність.

Yastrub Olena Mykolaivna, Candidate for Creative Postgraduate Studies (Doctor of Arts) at the Department of Interpretology and Music Analysis, Lecturer at the Choral Conducting Department of the Kharkiv I. P. Kotlyarevsky National University of Arts

\section{Lysenko's "The Christmas Night": a Ukrainian worldview in the XIX century}

Research objective. The purpose of the work is to actualize M. Lysenko's opera "The Christmas Night" (1872) in modern research discourse - as an incarnation of the national Ukrainian worldview. The methodology is based on the involvement of historiographical, genre, structural and functional methods. The scientific novelty is expressed in the involvement of the category "worldview" as a cognitive tool of analysis in the study of musical artifacts of national musical culture, in this case - of the first outstanding Ukrainian opera without conversational dialogues to the Ukrainian text, that is "The Christmas Night" by M. Lysenko, which opens the prospect to study the composer's operatic heritage, taking into consideration the system-forming function of the worldview as a scientific model of cognition. Conclusions. Based on the study, the fundamental criteria of the Ukrainian worldview, found in the opera "The Christmas Night" by M. Lysenko, were summarized: continuity (an appeal to the established principles of folk song tradition and rituals - traditional customs in general); spirituality (embodied through the appeal to the relevant genres of the folk song tradition associated with the celebration of Christmas, which are heard in the opera in choral episodes and scenes); musical logos (reconstitution of the principles of folk polyphony at the musical language level, embodied in choral episodes and scenes of the opera). After reviewing the current audio recordings of the opera "Christmas Night" (1952, 1958 and 1992) we come to the conclusion about the crucial importance of choral scenes in the opera and the value of each carol used by M. Lysenko. Thanks to the unique artistic concept of M. Lysenko's operatic masterpiece, a modern listener is able to comprehend the greatness of the national tradition in its hereditary relations. "The Christmas Night" is the embodiment of the Ukrainian worldview of the XIX century, the modern study of which, like other significant phenomena of national musical culture, from a historical distance opens the prospect of its evaluation and importance from the point of view of national cultural consciousness.

Key words: M. Lysenko's opera, choir, Ukrainian worldview, carol, spirituality.

Актуальність теми дослідження зумовлена науковим інтересом до творчості Миколи Віталійовича Лисенка, як відомо, - основоположника української національної 
композиторської школи, фольклориста, піаніста, диригента, громадського діяча, автора духовного гімну України «Боже, великий, єдиний» тощо. Оперна спадщина митця становить значний потенціал для ii наукового осягнення i в XXI столітті. 3-поміж грунтовно досліджених і знаних слухачеві опер митця, включених у репертуар оперних театрів сьогодення, затребуваним у науковій царині і сучасному культуротворчому процесі вбачається актуалізація інших, не менш знакових оперних шедеврів М. Лисенка. Як відомо, композитор є автором перших в Україні дитячих опер («Коза-дереза», 1880 р.; «Пан Коцький», 1891 р.; «Зима і весна», 1892 р.). Такі опери, як «Різдвяна ніч», «Утоплена», «Тарас Бульба» (свого роду оперний триптих на сюжети повістей М. Гоголя), на думку дослідників, стали «епіцентром оперних новацій композитора» [3, с. 188-189].

«Різдвяна ніч» визначається дослідниками як перша видатна українська опера без розмовних діалогів на український текст [8, с. 363]; як перша українська опера-колядка [3, с. 7]. Отже, прицільного наукового дослідження заслуговує «Різдвяна ніч», що стала фактично першою оперою митця, яка здобула широке визнання (постановки в Києві, Одесі, Львові) та пошану за життя композитора. Саме в цій опері втілились перші визначні новаторські принципи М. Лисенка в оперному жанрі, що визначають іiі знакову роль в історії національної музичної культури.

Мета дослідження полягає в актуалізації опери М. Лисенка «Різдвяна ніч» (1872 р.) у сучасному дослідницькому дискурсі як увиразнення національної української картини світу.

Наукова новизна. У науковій статті методологічним підгрунтям дослідження опери «Різдвяна ніч» М. Лисенка обрано картину світу як когнітивний інструмент, що в системі категорій аналізу музики враховує й увиразнює шкалу ціннісних орієнтирів української музичної культури, за визначенням дослідників ${ }^{1}$, i відкриває перспективу подальшого розроблення дослідження оперної спадщини композитора як цілісності, зважаючи на системоутворювальну функцію картини світу як наукової моделі пізнання.

1 У даному дослідженні ми спираємось на розробку картини світу як музичної парадигми, запропоновану в дисертаційному дослідженні I. Романюк ««Картина світу» у системі категорій аналізу музики (на прикладах української музичної культури)» [16]. 
Виклад основного матеріалу. 3-поміж розмаїтих музично-виконавських сфер хорова творчість є провідною як основа української музичної культури, за О. Бенч [1]; вона наділена «генетичним кодом» музичного мислення як жанрова домінанта національної української картини світу, за І. Романюк [16, с. 3]. Як визначає дослідниця, «саме традиція хорового співу $є$ репрезентантом національної ментальності протягом багатьох століть (від автентичного гуртового співу до вершинних зразків композиторської творчості - в акапельному та симфонічно-хоровому різновидах)» [там само].

Картина світу, за I. Романюк, - це спосіб наукового моделювання об'єктів музичної культури, завдяки якому взаємозумовленість зовнішньої комунікації (мови / логосу) внутрішнім змістом досліджуваного об'єкта спричиняє механізм його розуміння через усвідомлення ціннісної семантики (за критеріями спадкоємності, духовності, часопростору) [16, с. 7].

У даній статті дослідницьку увагу зосереджено на хорових епізодах і сценах опери «Різдвяна ніч» М. Лисенка, зважаючи на їхню вирішальну роль в увиразненні української картини світу (музичний логос картини світу). Репрезентація в оперному жанрі традиції автентичного гуртового співу, утілена саме в хорових епізодах та сценах, що постає значущою новацією композитора і надає їм вагомої ролі у драматургії опери. Спробуємо, послуговуючись залученням картини світу як когнітивного інструменту дослідження явищ національної музичної культури, на окремому прикладі увиразнити прояв ії критеріїв, визначених I. Романюк, як-от: спадкоємність «як закон, що забезпечує повноту ціннісної орієнтованості буття на кожному з етапів розвитку музичної культури - історична пам'ять культури, генетичні культурні коди тощо»; духовність як «ціннісна семантика релігійного досвіду в українській культурі»; музичний логос як «система принципів музичного мислення як семіотичний об'єкт» та відповідний йому часопростір [16, с. 13].

М. Лисенко, як відомо, є автором музики до 14 оперних сюжетів із різноманітною образною сферою. Опера «Різдвяна ніч», створена в 1872 р., стала фактично першою масштабною оперою митця на чотири дії без розмовних діалогів на український текст, після незакінченої опери «Гаркуша» й опери-сатири на дві дії «Андріашіада» [8, с. 363]. М. Лисенко серед перших у музично-театральному мистецтві втілив сюжет повісті «Ніч проти Різдва» М. Гоголя. 
Передусім убачаємо за доцільне закцентувати на окремих фактах, надати твердження та спогади різних авторів, віднайдені в наукових та публіцистичних джерелах, написані в різні роки, що розкривають підхід М. Лисенка в роботі над оперою «Різдвяна ніч» і увиразнюють здійснені в ній новації.

До київської постановки 1874 р. було запрошено автора лібрето та режисера опери «Різдвяна ніч», одного з корифеїв першого українського професійного театру Михайла Старицького; видатного українського етнографа і фольклориста, автора слів Гімну України Павла Чубинського; відповідав за декорації, костюми та реквізити один з основоположників української етнології, антропології й археології, дослідник Федір Вовк. Доходимо висновку, що навколо М. Лисенка гуртувався цвіт української еліти ${ }^{2}$. Працьовитість і етнографічна точність митця супроводжували весь період роботи над оперою «Різдвяна ніч». Наведемо цитату зі «Спогадів про батька» Остапа Лисенка: «Не один пуд солі ми з Михайлом (Старицьким - O. Я.) з"їли, не один віз паперу перевели, - згадував батько, - поки добрались до гоголівської «Різдвяної ночі»» [11, c. 98$]$.

Зі слів Олени Пчілки, які наводить Р. Скорульська, стає відомо, що на репетиціях були присутні відомі вчені, історики, етнографи, що вказували на важливі аспекти втілення на сцені народного побуту, особливостей вимови тексту опери [17].

Етнограф та музикознавець Люцій Кобилянський, який був учасником хору М. Лисенка, так визначає роль опери «Різдвяна ніч»: «Се не просто молодий композитор виставляв свою першу оперу - се першу українську оперу виставляв перший український композитор з європейською вищою музичною освітою» [6, с. 223]. Л. Кобилянський став свідком такого діалогу під час антракту: «- І охота отсе вам, Миколо Віталійовичу, вовтузитись $з$ тією «хахлаччиною». Вона ж вам не дасть ані слави, ані хліба. Облиште! < ..> Вам Бог дав талант не на те, щоб його отак марнувати. А Лисенко, вклонившись низенько, одказує: - Спасибі вам велике за вашу пораду! Але, вибачайте, - «теплий кожух, та не на мене шитий». Я дякую

2 М. Лисенко листувався 3 I. Франком, I. Нечуєм-Левицьким, Г. Барвінок, П. Кулішем та іншими видатними постатями і діячами культури України. 
Богові за його велику милість до мене і заприсягаюсь той талан, що його послав мені Господь, присвятити тільки своїй рідній Україні і служити їй до кінця мого віку!» [6, с. 225].

Олена Пчілка пізніше напише про постановку опери в 1874 р.: «Можливо, що колись-там ставитимуть «Різдвяну ніч» Лисенкову хитрі-мудрі «оформники» й режисери, а виконуватимуть видатні оперні співці й співачки; та чи буде в усіх тих митців стільки етнографічного знання й розуміння українського життя, побуту, стільки бажання вірно подати його, без пересади, без чудернацтва?» [15, с. 111].

«Різдвяна ніч» постала як результат самобутньої композиторської інтерпретації М. Лисенком жанру опери в умовах історико-культурного періоду, що пов'язаний в історії України зі зростанням національного руху та самосвідомості. Музикознавець та диригент Я. Полфьоров визначає такі прикметні ознаки даного періоду: «<...> українська культура іде під яскраво виявленим національним ренесансом, боротьба за національну незалежність, ствердження свого національного буття» $[14$, с. 6].

До новаторських ознак опери «Різдвяна ніч» Л. Корній відносить створення М. Лисенком дійових народних сцен, у яких відтворено обряд колядування [8, с. 366]. У рецензії I. Франка на постановку опери 17 грудня 1890 р. дізнаємось: «Музика, яку до цього лібретто написав Лисенко, принаймні у своїй вокальній частині, наскрізь народна, українська $<\ldots>$. Нарешті, чільне місце в цій опері займають хори» [18]. Побут українського села став тим тлом в опері, на якому розгортається історія кохання Вакули й Оксани. «Колядкові» хорові епізоди, за термінологією Л. Корній [8, с. 379], своїм піднесеним, величним, святковим образним строєм вносять контраст до попередньої дії. Т. Булат і Т. Філенко вказують, що хори стають лейтмотивом свята в опері та одним із важливих чинників драматургічного розвитку: «Композитор вивів народну колядку і щедрівку на рівень оперної драматургії» [3, с. 191].

Зупинимось детальніше на хорових сценах і епізодах опери «Різдвяна ніч». «Колядкові» хорові епізоди супроводжують першу та другу дії опери і представлені у звучанні колядок: «Добрий вечір тобі, пане господарю», «Чи дома, дома бідная вдова» (І картина першої дії); колядки / духовного канту «Ой дивнеє народження Божсго сина», колядки «Чи дома, дома бідная вдова» (звучить вдруге) та великої хорової сцени першої 
дії II картини («Ходив, походив місящь по небі», «Ой співали три янголи»).

Перший «колядковий» хоровий епізод опери (I картина першої діi) представлений у моносцені, пов'язній з експозицією образу головної героїні Оксани, колядкою «Добрий вечір тобі». Розпочинається іiі звучання із приспіву за сценою «Радуйся, ой радуйся земле», авторська ремарка у клавірі: "Стиха співають за сиеною, з дуже невеличким хіба підвищенням». Можна припустити, композитор застосовує такий виконавський прийом, спрямований на досягнення «автентичності» звучання. За словами І. Куриляк, поява першого заспіву колядки, який звучить другим планом, відіграє «роль образного камертона» [9, с. 96].

Хорова фактура заснована на засадах музичної стилістики народнопісеннної традиції (унісони в кадансах, синхронність за вертикаллю, паралельний рух секстами, розвиненість партії баса), що загалом створює відповідний звуковий акустичний та тембральний простір. В оркестровій партії звучать тематичні елементи колядки (вкраплення піцикато), що надає всій фактурі підголосковості та зображальності. У партії валторни квінтовий витриманий тон (два такти) сприймається як органічна складова частина хорової фактури. Лише в завершальному кадансовому звороті з'являються ознаки щільної гомофонно-гармонічної фактури, що зумовлює компактність звучання.

Після завершення урочисто-піднесеного звучання колядки за сценою в чоловічому виконанні жіноча група хору attacca заспівує іншу колядку «Чи дома, дома бідная вдова» у світлому однойменному ладі $(D-d u r)$ на тлі витриманого тонічного органного пункту в оркестрі (у дерев'яних духових). Звернемо увагу, що це один із небагатьох прикладів хорової фактури в опері, де заспівують у два голоси. Поява нової ритмоформули (3/4) з нерівномірним збігом сильної та слабкої долей визначає подальший ритмічний розвиток музичного тематизму. Засобами фактурної ускладненості в розвитку голосових ліній (утілено у продовженому звучанні першої колядки на словах «Радуйся, ой радуйся земле») спостерігаємо імпровізаційну природу викладення тенорової та басової партій. Такий прийом $є$ характерним для українського народнопісенного багатоголосся. Спостерігається підкреслення характерних зворотів та інтонацій 
кожної з колядок у поєднанні з наскрізним типом розвитку. За Т. Булат, у хорах опери «Різдвяна ніч» утілена «<..> специфіка вулишнього співу, коли звучання різних за мелодією чоловічих і жіночих хорів накладається одне на одне, творячи надзвичайно цікаву поліфонію і гармонію» [3, с. 191]. Поступове динамічне зростання (росо crescendo протягом трьох тактів) стає сталим прийомом і вагомим чинником у побудові драматургії хорових сцен колядування в опері. У даному разі таким способом, з поступовим затиханням (росо a poco dimin. smorzando) закінчується звучання колядки на словах: «Що перший же празник святеє Рождество, радуйся <...>. Звучання постійно послаблюється до крайньої точки, повернення початкового розміру 4/4 знаменує завершення даного епізоду.

У другому «народному» хоровому епізоді опери звучить колядка (духовний кант, за Л. Корній) у виконанні дівчат-колядниць: «Ой дивнеє народження Божсого Сина» 3 авторською ремаркою Andante religioso (повільно, релігійно) та non forte (неголосно). Таким чином підкреслюється першорядність духовного першоджерела на тлі розгортання любовної колізії головних персонажів (Оксана і Вакула). Прикметним є такий факт: М. Лисенко вважав, що «<..> людські колядки мають перевагу перед церковними, <...>, бо й у церковній колядці мотив має зв'язок із народною піснею» [13, с. 2]. Також i О. Бенч, аналізуючи етнокультурні витоки українського хорового співу, констатує: «<..> На основі обрядового хорового співу сформувалася українська церковно-музична культура, пристосувавши первинну обрядову культуру до церковних календарних богослужінь» [1, с. 16].

Музична мова даного хорового епізоду насичена архаїчними рисами гармонізації, маємо на увазі мінливість ладу (гармонічного та натурального $d$-moll), спостерігаємо імпровізаційну природу музичного тематизму кожного із трьох куплетів, утілену, серед іншого, у появі мелодичних фігурацій у партії сопрано тощо. Композитор користується принципами народного багатоголосся, що втілюється в: октавних потовщеннях, появі унісонного заспіву на першій долі з подальшим триголосним розвитком (у другому та третьому куплетах), октавних унісонах у кадансах, терцієвих вторах, кварто-квінтових гармонічних співвідношеннях, ферматах у завершенні кожного куплета без застосування пауз. 
Змальовуючи образний стрій даного хорового епізоду («Ой дивнеє народження Божсого Сина»), звернемось до твердження О. Козаренка: «Лисенком збережена не тільки «буква» національної духовно-музичної традиції <...>, а й, що найважливіше, сам дух вітчизняної церковної музики із притаманною їй медитативністю, кордоцентризмом, тихою світлою радістю в пережитті релігійного почуття» [7, с. 122].

До третього хорового епізоду, пов'язаного 3 обрядом колядування, належить виконання дівчатами-колядницями «Чи дома, дома бідная вдова», що як лейттема опери звучить удруге.

Велика хорова сцена II картини першої дії складається із трьох колядок (парубоча «Ходив, походив місяиь по небу» та дівоча «Ой співали три янголи»), де в хоровому фіналі, накладаючись одна на одну, звучать дві колядки «Ой співали три янголи» та «Чи дома, дома бідная вдова». Це - одна $з$ найсвітліших хорових сцен опери «Різдвяна ніч» загалом (за характером звучання та темброво-інтонаційним співвідношенням хорових груп).

Наближення парубочого гурту з колядкою «Ходив, походив місяиь по небу» (уперше в опері звучить спів a cappella) створює відчуття реальності обрядової події: «Парубоча колядка оддалеки. Попереду Грицько і зіркою, Тиміш з торбою через плече. Ідуть на вулиці, через сиену, під вікно до хати. Ідучи, співають. Колядка за сценою» [10, с. 128].

Розвиток драматургії заснований на поступовому динамічному зростанні в масштабах чотирьох куплетів (варіаційний принцип розвитку), з різними фактурними видозмінами, від унісонних проведень до прозорих імітаційних підголосків, iз завершенням кожного куплета 3 ферматою на домінанті. В одному з листів М. Лисенка до Ф. Колесси, датованому 22 квітня 1896 р. (після написання опери «Різдвяна ніч»), композитор зазначає: «<..> Народ узагалі, співаючи гуртом, не окселентує $\epsilon^{3}$ однаковими підряд інтервалами; у нього унісон розходиться в сексту, далі - в октаву, терцію і далі <...>» $[12$, с. 270].

Поява колядки «Ой співали три янголи» (B-dur) у жіночому виконанні, «Оддалеки, десь з другого кутка на селі чутно дівочу колядку стиха» [10, с. 131], увиразнена зміною метру на

\footnotetext{
3 Вторить.
} 
близькій відстані, відзначена авторською ремаркою Larghetto religioso, характеризується кантовим триголоссям, 3 наявною синкопованою ритмоформулою. В оркестровій партії превалюють тембри духових інструментів, відіграючи роль фону; уперше звучать дзвони та вкраплення піцикато струнних.

За другим заспівом звучать уже дві колядки («Ой співали три янголи» та «Чи дома, дома бідная вдова»), де поліритмічний та поліметричний хоровий масив у такому вокально-симфонічному дійстві звучить як кульмінація всієї хорової сцени з подальшим тривалим хоровим діалогом жартівливого характеру. Полішаровість вертикалі як характерна риса народної традиції одночасного виконання кількома гуртами пісень утілена в хоровому багатоголоссі під час виконання двох колядок: у чоловічому та жіночому виконанні хорового фіналу II картини першої дії опери.

Отже, в оперній драматургії «Різдвяної ночі» М. Лисенко втілює прикметні ознаки святкування Різдва Христового через наслідування традиції «вулишного співу» колядників [3, с. 192]. Т. Булат і Т. Філенко вказують на жанрову оригінальність та новаторську сутність драматургії опери, яка втілилась у хорових сценах і епізодах, не втративши «первісної фольклорно-театралізованої функції різдвяного обряду, у якому масове дійство є імпровізованою грою» [3, с. 192].

О. Бенч зазначає, що в контексті обрядових дійств Різдвяних свят роль колядників $є$ вирішальною. «Колядники молитвоспівами-колядками розпочинають і завершують весь цикл Різдвяних свят і творять релігійно-ідейний зміст Свята. Донині саме в колядках і щедрівках збереглися дуже старі наверстування давньої української природної традиції» [1, с. 34]. У творчості М. Лисенка, зокрема в опері «Різдвяна ніч», етнографізм вивершився до високого професійного західноєвропейського рівня, продовжуючи думку Б. Грінченка, «<..> набрав усесвітньо-визнаних форм» [5, с. 48].

Висновки. На підставі здійсненого дослідження узагальнимо прояв визначальних критеріїв української картини світу, виявлених в опері «Різдвяна ніч» М. Лисенка:

- спадкоємність (апелювання до усталених засад народнопісенної традиції та обрядових дійств - традиційної звичаєвості загалом);

- духовність (утілена через звернення до відповідних жанрів народнопісенної традиції, пов'язаних з оспівуванням 
Різдва Христового, які звучать в опері в хорових епізодах і сценах);

- музичний логос (наслідування принципів народного багатоголосся на рівні музичної мови, що втілюється в хорових епізодах та сценах опери).

У наш час в інтернет-ресурсах фігурують три аудіозаписи опери «Різдвяна ніч» М. Лисенка: записи Українського радіо 1952 та 1958 рр. (постановка Київського оперного театру під орудою диригента Петра Полякова, хормейстер - Юрій Таранченко), у яких вилучені хорові «колядкові» епізоди (крім першого і колядки «Ходив походив місяць по небі», поданої звучанням першого куплета в записі опери у скороченому вигляді 1958 р.). Постановка опери 1992 р. (Львівський оперний театр, диригент - Ігор Лацанич, хормейстер - Орест Кураш) представлена без купюр. На підставі ознайомлення 3 даними записами доходимо висновку про вирішальне значення хорових сцен в опері та цінності кожної із задіяних М. Лисенком колядок, вилучення яких з опери унеможливлює втілення художнього задуму в повноті.

Завдяки унікальній художній концепції оперного шедевра М. Лисенка сучасний слухач здатен осягнути велич національної традиції в іiї спадкоємних зв'язках. «Різдвяна ніч» постає втіленням української картини світу XIX століття, дослідження якої, як і інших знакових явищ національної музичної культури, у наш час з історичної дистанції відкриває перспективу іiі оцінки і значення під кутом зору національної самосвідомості культури.

\section{СПИСОК ЛІТЕРАТУРИ}

1. Бенч-Шокало О. Український хоровий спів: Актуалізація звичаєвої традиції : навчальний посібник. Київ : Ред. журн. «Укр. світ», 2002. $440 \mathrm{c}$.

2. Булат Т. Микола Лисенко. Київ : Музична Україна, 1973. $105 \mathrm{c}$.

3. Булат Т., Філенко Т. Світ Миколи Лисенка. Національна ідентичність, музика і політика України XIX - початку XX століття. Нью-Йорк : Українська вільна академія наук у США ; Київ : Майстерня книги, 2009. 408 с.

4. Голинська О. Микола Гоголь та українська національна опера. Музика : український інтернет-журнал. 2016. URL: http:// mus.art.co.ua/mykola-hohol-ta-ukrajinska-natsionalna-opera/.

5. Грінченко М. Історія української музики. Київ : Спілка, 1922. 290 c. URL: http://irbis-nbuv.gov.ua/ulib/item/UKR0004375. 
6. Кобилянський Л. Спомини про М. В. Лисенка. «Різдвяна ніч». M.В. Лисенко у спогадах сучасників / упор. О. Лисенка ; ред., комент. Р. Пилипчука. Київ : Муз. Україна, 1968. С. 217-229.

7. Козаренко О. Українська національна музична мова: генеза та сучасні тенденції розвитку : автореф. дис. ... докт. мистецтвозн.: 17.00.03. Київ, 2001. 36 с.

8. Корній Л. Історія української музики : підручник. Київ ; НьюЙорк : Видавництво М.П. Коць, 2001. Ч. 3 : ХІХ ст. 480 с.

9. Куриляк I. Еволюція драматургічних функцій хору в українській опері: національно-естетичний вимір : дис. ... канд. мистецтвозн.: 17.00.03. Львів, 2018. 196 с. URL: https://lnma.edu.ua/ wp-content/uploads/2018/02/kuryljak-dysertacija.pdf.

10. Лисенко М. Різдвяна ніч : коміко-лірична опера на 4 дії. [клавір]. T. IV. Лібретто М. Старицького (за одноіменною повістю М. Гоголя) / муз. ред. Л. Ревуцького ; літ. ред. М. Рильського. Зібрання творів : у 20-ти т. / М. Лисенко. Київ : Мистецтво, 1953. $385 \mathrm{c}$.

11. Лисенко О. Де моє, а де не моє. Спогади про батька. 5-е вид. Київ : Музична Україна, 1991. С. 94-100.

12. Лист М.В. Лисенка до Ф.М. Колесси № 242 від 22 квітня 1896 р. Лисенко М.В. Листи / упор., прим. та комент. О. Лисенка. Київ, 1964. С. 270.

13. Листи Лисенка. Музика. 1927. № 2. С. 26-27. URL: https:// elib.nlu.org.ua/uchasnyky.html?id=7.

14. Полфьоров Я. Микола Лисенко е світі сучасности. Музика. 1927. № № 5-6. C. 4-23. URL: https://elib.nlu.org.ua/catalogue. html? catalogue $=39$.

15. Пчілка О. Микола Лисенко : спогади і думки. Микола Лисенко y спогадах сучасників / упоряд. О. Лисенка ; ред., комент. Р. Пилипчука. Київ : Муз. Україна, 1968. С. 63-182.

16. Романюк I. «Картина світу» у системі категорій аналізу музики (на прикладах української музичної культури) : автореф. дис. ... канд. мистецтвозн.: 17.00.03. Харків, 2009. 17 с.

17. Скорульська Р. «Різдвяна ніч» Лисенка в Києві. Музика. 2014. URL: http://mus.art.co.ua/persha-ukrayins-ka-opera-na-kiyivs-kijstseni/.

18. Франко І. «Різдвяна ніч» М. Старицького - М. Лисенка. Зібрання творів : у 50-ти т. / І. Франко. Київ : Наукова думка, 1980. T. 28. C. 110-111. URL: https://www.i-franko.name/uk/Misc/1890/ RizdvjanaNich.html.

\section{REFERENCES}

1. Bench-Shokalo, O. (2002). Ukrainian choral singing: Actualization of customary tradition. Teaching. way. K. : Red. zhurn. "Ukr. Svit", 40 p. [in Ukrainian].

2. Bulat, T. (1973). Mykola Lysenko. Kyiv : Muzychna Ukraina, 105 p. [in Ukrainian]. 
3. Bulat, T., Filenko, T. (2009). The world of Mykola Lysenko. National identity, music and politics of Ukraine in the XIX - early XX centuries. New York: Ukrainska Vilna Akademiia Nauk u SShA; Kyiv : Maisternia knyhy, 408 p. [in Ukrainian].

4. Holynska, O. (2016). Mykola Gogol and Ukrainian National Opera. Muzyka. Ukr. internet-zhurnal [in Ukrainian].

5. Hrinchenko, M. (1922). History of Ukrainian music. Kyiv: Spilka, 290 p. [in Ukrainian].

6. Kobylianskyi, L. (1968). Memories of M.V. Lysenko. "Christmas night”. M.V. Lysenko u spohadakh suchasnykiv. Kyiv : Muz. Ukraina, pp. 217-229 [in Ukrainian].

7. Kozarenko, O.V. (2001). Ukrainian national musical language: genesis and modern development trends. Extended abstract of Candidate's thesis. Kyiv, 36 p. [in Ukrainian].

8. Kornii, L. (2001). History of Ukrainian music. Part of the third. XIX century. Kyiv - New York : Vydavnytstvo M.P. Kots, 280 p. [in Ukrainian].

9. Kuryliak, I. (2018). Evolution of drama functions of the choir in the Ukrainian opera: national-aesthetic dimension. Candidate's thesis. Muzychne mystetstvo. Lviv, 196 p. [in Ukrainian].

10. Lysenko, M. (1953). Christmas Night: Comic-Lyrical Opera for 4 Actions. Tom IV. Zibrannia tvoriv v dvadtsiaty tomakh. Kyiv : Mystetstvo, 385 p. [in Ukrainian].

11. Lysenko, O. (1991). Where mine and where is not mine. Memories. 5-e vyd. Kyiv : Muzychna Ukranna, pp. 94-100 [in Ukrainian].

12. Lysenko’s M. V. Letter to F.M. Kolessa. № 242 of April 22, 1896. Kyiv, 1964. P. 270 [in Ukrainian].

13. Lysenko's letters (1927). Muzyka. 2, pp. 26-27 [in Ukrainian].

14. Polforov Ya. (1927). Mykola Lysenko in the world of modern times. Muzyka, 5-6, pp. 4-23 [in Ukrainian].

15. Pchilka O. (1968). Mykola Lysenko (memories and opinions). Mykola Lysenko in the memoirs of contemporaries. Kyiv : Muz. Ukraina, pp. 63-182 [in Ukrainian].

16. Romaniuk, I. (2009). "The World-View" in the system of music analysis categories (on examples of the Ukrainian musical culture). Extended abstract of Candidate's thesis. Kharkiv I.P. Kotlyarevsky National University of Art, 17 p. [in Ukrainian].

17. Skorulska, R. (2014). "Christmas Night" Lysenko in Kyiv. Muzyka [in Ukrainian].

18. Franko, I. (1980). "Christmas Night” M. Starytsky - M. Lysenko. Collection of works in 50 volumes. K. : Naukova dumka, Vol. 28, pp. 110-111 [in Ukrainian]. 